\title{
FIELD TRIALS TO EVALUATE DAMAGE CAUSED BY WILD BIRDS TO CERTAIN FIELD CROPS UNDER DIFFERENT HABITATS AT ASSIUT GOVERNORAT
}

\author{
Metwally, A.M. ${ }^{1}$ M.A. Ahmed ${ }^{2}$; N.A. Mahmoud ${ }^{2}$ and \\ M.M.Abdel-Aal ${ }^{2}$
}

1- Agric. Zoology and Nematology Dept., Fac. of Agric., Al-Azhar Univ., Cairo, Egypt.

2- Agric. Zoology and Nematology Dept., Fac. Of Agric., Al-Azhar Univ., Assiut, Egypt.

\begin{abstract}
Field trials were carried out under different habitats at Assiut Governorate to assess the damage caused by house sparrow birds in some field crops during the year of 2003 and 2004. Two experiments were carried out on the wheat crop as well as on long and short variety of sorghum crop; the first one in old lands the other in newly reclaimed land. The damage percentage was recorded in different growth stages till crop harvesting.

The obtained results indicated that there were significant differences between the damage which caused by house sparrow in old land ( $1.6 \& 1.23 \%)$ and that happened in newly reclaimed land $(0.40 \& 0.34 \%)$ during $2003 \& 2004$. The Sparrows attacked the eaten crop starting from formation milky stage with highest damage percent in dough stage during the two seasons (2003 \& 2004). The damage percentage was not recorded in appearance of ears stage and flowers that prevent the sparrow from attacked the ears during completion mature of seeds.

Concerning different habitat, the results revealed that there were highly significant differences between damage percentage in sorghum crop for both varieties (Giza 15 \& Dorado) in old land, the value being 14.26 and $12.94 \%$ during 2003 and 2004 , respectively. While in the newly reclaimed land, the values of damage percentage were 5.54 and $2.32 \%$ during 2003 and 2004, respectively. The highest damage percentage was noticed in the long variety of sorghum (Giza 15) at old land and newly reclaimed land (15.56 \& $12.24 \%)$, while the damage percentage in short stem variety (Dorado) was 2.24 and $3.02 \%$ during 2003 and 2004 , respectively. The bird caused damage by attacking the sorghum crop starting from the milky and doughy stages then increased gradually till the harvest time.

Keywords: House sparrow, damage percent, wheat, sorghum, old land, newly
\end{abstract} reclaimed land.

\section{INTRODUCTION}

Certain bird species have become closely associated with man and his own activities. This association may merely consist of using man-made structures for perching or even nesting. At the other extreme, his crops may be utilized as food. In addition, birds may be incriminated in transmitting the causative agents of plant diseases such as viruses bacteria and fungi. On the other hand, they may be considered as natural enemies to Reptiles, Redontia, and some harmful Arthropoda.

Many efforts have been carried out in order to assess the damage caused by birds on some field crops and orchards. Soliman (1999) studied 
the damage caused by Cattle egret to flowers and fruits of orange, Tolba (1999) studied the damage caused by the house sparrow, passer domesticus nilotcus to certain cultivars of broad bean and wheat, in addition to some orchard crops in Assiut Governorate .Recently,many efforts have been carried out to alleviate the bird problem in Egypt and other countries . The assessment of damage caused by certain birds to field and orchard crops and the efficacy of the traditional and the renewal techniques of bird control as apart of integrated crop protection ( I C P ) have been studies by many authors ( i . e ., Coleman et al 2001 ) ; Khan ( 2002 ) ; and Muhammad ( 2004 ) in Pakistan and Abdel - Gawad et al ( 2004 ) in Egypt. The current research aims to assess the damage caused by House sparrow, Passer domesticus niloticus and Palm dove, Streptopelia senegalensis egyptica in some field corps such as Wheat, Sorghum and Broad bean.

\section{MATERIALS AND METHODS}

Assessment of bird damage was monitored during 2003 and 2004 on different crops at different habitats (the traditional agricultural old lands and newly reclaimed lands). From the field observations it was noticed that house sparrow (Passer domesticus niloticus) and Palm dove (Streptopelia senegalensis) were attacked ripening stages of the Wheat and Sorghum crops. Assessment of bird damage on different stages of the studied crops was carried out according to the following methods:

\section{1- Assessment damage of the Wheat crop:}

Two experiments were carried out during 2003 / 2004 on the Wheat crop; the first experiment was carried out in old lands. In each type were 2 feddans taken and selected at random in the experimental area. Sampling was done according to the methods adopted by Poche et. al., (1982), a wooden square meter frame was used for 25 times in random at different portions of selected fields. The percentage of each ear was calculated according to Tolba (1999). The attacked plants were estimated as a percentage from the total examined plant $\%$

Damage $\%=(A / T) \times 100$

Where $A=$ attacked plants $\quad T=$ total investigated plants.

The second experiment on the wheat crop was carried out in old lands. Twenty feddans were cultivated with wheat crop in faculty of Agriculture farm, this experiment was carried 3 sites cultivated areas: Tested habitats could be discussed in detail follows:

The first site was the area adjacent to the buildings, the trees and cultivated areas of wheat crop. The second site was selected random at mid of the cultivated area which the houses and the trees. The third site was cultivated signal and surrounded by casuarina trees, fruit threes and the buildings. Two feddans, were selected in each sites as mentioned above, it was divided into 3 plots. Every plot was divided into five subplots. The samples were taken weekly starting from the appearance of ears till the harvest (one meter square from sub plot). 


\section{2- Assessment damage of Sorghum crop:}

The damage in sorghum was estimated by taking samples from two varieties of Sorghum differed in length and planted in two different types of lands in Assiut district. The first was the old lands of faculty of Agriculture farm Al-Azhar University. The second is newly reclaimed land of Mankabad district. In each type of land two feddans was selected at randomly. Five replicates were taken from each area. (Four replicates were taken from the borders of the field and the other replicate was taken from middle of the field. To estimate the degree of damage in the head / plant, percentage of damage was calculated by the above Mentioned equation. Also, the damage incident caused by House sparrow (Passer domesticus niloticus and Palm dove Streptopelia senegalensis egyptica, and other bird species.

\section{RESULTS AND DISCUSSION}

\section{1- Wheat crop (Tritcum sp):}

Data in Tables (1) which illustrated in Fig. (1) show the damage caused by House sparrow Passer domesticus niloticus (L.) in wheat crops (Tritcum $\mathrm{sp}$ ) in the different two habitats in Assiut district comprised the old land and newly reclaimed land during $2003 \& 2004$ seasons. The results revealed that there was highly significant difference between the old land and newly reclaimed land whereas in old land the mean of total damage was (1.64 \& $1.23 \%)$ during $2003 \& 2004$ comprised with the mean of total damage in newly reclaimed land $(0.40 \& 0.34 \%)$ during $2003 \& 2004$. Similar results were also observed by Wilson (1993) who noticed that the bird damage on all considered field crops was higher at the traditional areas than the newly reclaimed ones in Egypt. Also, Tolba (1999) found that the damage caused in wheat crops were caused by House sparrow Passer domesticus niloticus (L.).

Table (1): Average damage percentage caused by house sparrow in wheat crop during 2003 and 2004 In old and newly reclaimed land.

\begin{tabular}{|c|c|c|c|c|c|c|c|}
\hline \multirow{2}{*}{ Year } & \multirow{2}{*}{ Habitat } & \multicolumn{7}{|c|}{ Examined date } \\
\cline { 2 - 8 } & & $\mathbf{3 / 3}$ & $\mathbf{1 8 / 3}$ & $\mathbf{2 / 4}$ & $\mathbf{1 7 / 4}$ & $\mathbf{2 / 5}$ & Mean $^{*}$ \\
\hline \multirow{3}{*}{2003} & Old land & 0.0 & 0.08 & 2.68 & 2.72 & 2.72 & 1.64 \\
\cline { 2 - 8 } & Newly reclaimed land & 0.0 & 0.36 & 0.44 & 0.60 & 0.60 & 0.40 \\
\cline { 2 - 8 } & Mean $^{*}$ & $0.0 \mathrm{~B}$ & $0.22 \mathrm{~B}$ & $1.56 \mathrm{~A}$ & $1.66 \mathrm{~A}$ & $1.66 \mathrm{~A}$ & ------ \\
\hline \multirow{3}{*}{2004} & & $5 / 3$ & $20 / 3$ & $4 / 4$ & $19 / 4$ & $4 / 5$ & Mean \\
\cline { 2 - 8 } & Old land & 0.0 & 0.16 & 1.44 & 2.28 & 2.28 & 1.23 \\
\cline { 2 - 8 } & Newly reclaimed land & 0.0 & 0.24 & 0.44 & 0.52 & 0.52 & 0.34 \\
\cline { 2 - 8 } & Mean $^{*}$ & $0.0 \mathrm{~B}$ & $0.20 \mathrm{~B}$ & $0.94 \mathrm{~A}$ & $1.40 \mathrm{~A}$ & $1.40 \mathrm{~A}$ & ------ \\
\hline
\end{tabular}

* Mean with the same letter are highly significantly differed by using Duncan's analysis.

The results showed in table (1) revealed that there was a highly significant difference between the examination dates of damage caused by house sparrow of wheat crops during $2003 \& 2004$. The results revealed that 
Metwally, A.M. et al.

the sparrows started to attack the plants after 15 days from starting appearance of spikes till ripeness stage of grains in wheat crop during 2003 \& 2004. It has been observed that the minor percent damage was recorded after the first examination of crop and increase gradually till the ripeness grins stage $(0.00,0.22,1.56,1.66,1.66 \%)$ during 2003 and $(0.00,0.20,0.94,1.40$, $1.40 \%$ ) during 2004. But seldom causing damage by sparrows after ripeness stage may be due to the morphological features of the plants or spikes.

Fig. (1): Damage percentage caused by house sparrow in different habitats of wheat during year 2003 and 2004.

The previous results in agreement with those obtained by Soliman (1993) who reported that the average percentage of bird damage on milky, dough and mature stages of wheat during both year seasons of 1990 \& 1991 in wheat fields under the conditions of different three habitats in Kafr ALSheikh Governorate. Also, Khattab (1993) stated that throw the light on damage due to birds at ripening stage for wheat, barely and rice under the conditions of different habitats of old land and newly reclaimed land at Sharkia Governorate during 1991. Also, Metwally et. al (1995) revealed that the average percentage of pest birds damage on ripening stage of wheat and barely crops under the conditions of different habitat of old land and newly reclaimed areas at Sharkia Governorate during 1991 to 1992. Also, Tobla (1999) stated that the maximum damage caused by Sparrows was recorded during the milky and doughy stages and decreases of the ripeness of grains in both varieties of wheat. 


\section{2- Sorghum Crops (Sorghum vulgar ) :}

Data in Table (2) that illustrated in Fig. (2) show the damage caused by House sparrow, Passer domesticus niloticus (L.) and Palm dove, Streptopelia sengegalensis (L.) in two habitats (old lands and newly reclaimed land) in Assiut district. Also, the table showed that in both habitat were the experimental area where planted with two varieties of Sorghum differed in length (Giza 15 with long stem; Dorado with short stem) during 2003 \& 2004. Data in Table mentioned above show that there was significant difference between the different tested habitats whereas the mean highest in old land $(14.26 \%)$ while in newly reclaimed land was the mean (5.54\%) during 2003 season comparison at 2004.

The data indicated that there was highly significant difference between the habitats mentioned above since the highest damage mean in old land was 12.94, while newly reclaimed land it was 2.32. The variation in the percentage of bird damage between planted habitats of Sorghum crop may be due mainly to the variation in phonology of the sorghum varieties and more in planted area at Sorghum crops. Soliman (1993) stated that on Sorghum damage was higher in old land $(23.9 \%)$ than in newly reclaimed land $(19.2 \%)$. The results showed the table above mentioned revealed that there was highly significant difference between two varieties (Giza 15 and Dorado. Whereas, the mean are highest in Giza 15 (15.56 \& 12.24) wile in Dorado variety were the mean (4.24 \& 3.02) during 2003 \& 2004 .

Table (2): Average damage percentage caused by wild birds in sorghum crop during 2003 and 2004 In old and newly reclaimed land

\begin{tabular}{|c|c|c|c|c|c|c|c|c|}
\hline \multirow{2}{*}{ Year } & \multirow{2}{*}{ Habitat } & \multirow{2}{*}{ Variety } & \multicolumn{6}{|c|}{ Examined date } \\
\hline & & & $31 / 8$ & $7 / 9$ & $14 / 9$ & $21 / 9$ & $28 / 9$ & Mean* \\
\hline \multirow{9}{*}{2003} & \multirow{3}{*}{ Old land } & Giza 15 & 5.60 & 12.40 & 20.40 & 38.20 & 39.80 & $23.28 \mathrm{~A}$ \\
\hline & & Dorado & 0.20 & 1.00 & 3.20 & 9.80 & 12.00 & $5.24 \mathrm{~B}$ \\
\hline & & Mean* & $2.90 \mathrm{C}$ & $6.70 \mathrm{C}$ & $11.80 \mathrm{~B}$ & $24.00 \mathrm{~A}$ & $25.90 \mathrm{~A}$ & 14.26 \\
\hline & \multirow{3}{*}{$\begin{array}{c}\text { Newly } \\
\text { reclaimed } \\
\text { land }\end{array}$} & Giza 15 & 5.20 & 6.40 & 8.20 & 9.60 & 9.80 & $7.84 \mathrm{~B}$ \\
\hline & & Dorado & 1.00 & 1.80 & 2.80 & 5.00 & 5.60 & $3.24 \mathrm{~B}$ \\
\hline & & Mean* & $3.10 \mathrm{C}$ & $4.10 \mathrm{C}$ & $5.50 \mathrm{C}$ & $7.30 \mathrm{BC}$ & $7.70 \mathrm{BC}$ & 5.54 \\
\hline & \multirow{2}{*}{ Mean } & Giza 15 & 5.40 & 9.40 & 14.30 & 23.90 & 24.80 & 15.56 \\
\hline & & Dorado & 0.60 & 1.40 & 3.00 & 7.40 & 8.80 & 4.24 \\
\hline & \multicolumn{2}{|c|}{ Mean* } & $3.00 \mathrm{C}$ & $5.40 \mathrm{C}$ & $8.65 \mathrm{~B}$ & $15.65 \mathrm{~A}$ & $16.80 \mathrm{~A}$ & -------- \\
\hline \multirow{10}{*}{2004} & & & $30 / 8$ & $6 / 9$ & $13 / 9$ & $20 / 9$ & $27 / 9$ & Mean* \\
\hline & \multirow{3}{*}{ Old land } & Giza 15 & 5.20 & 15.00 & 21.80 & 29.60 & 34.60 & $21.24 \mathrm{~A}$ \\
\hline & & Dorado & 0.00 & 0.00 & 4.40 & 8.20 & 10.60 & $4.64 \mathrm{~B}$ \\
\hline & & Mean* & 2.60EFG & $7.50 \mathrm{D}$ & $13.10 \mathrm{C}$ & $18.90 \mathrm{~B}$ & $22.60 \mathrm{~A}$ & 12.94 \\
\hline & \multirow{3}{*}{\begin{tabular}{|c|} 
Newly \\
reclaimed \\
land \\
\end{tabular}} & Giza 15 & 0.00 & 1.20 & 3.00 & 5.00 & 7.00 & $3.24 \mathrm{~B}$ \\
\hline & & Dorado & 0.00 & 0.00 & 1.60 & $2.40 \mathrm{GH}$ & $3.00 \mathrm{GH}$ & $1.40 \mathrm{~B}$ \\
\hline & & Mean* & $0.00 \mathrm{G}$ & $0.60 \mathrm{FG}$ & 2.30 EFG & $3.70 \mathrm{EF}$ & $5.00 \mathrm{DE}$ & 2.32 \\
\hline & \multirow{2}{*}{ Mean } & Giza 15 & 2.60 & 8.10 & 12.40 & 17.30 & 20.80 & 12.24 \\
\hline & & Dorado & 0.00 & 0.00 & 3.00 & 5.30 & 6.80 & 3.02 \\
\hline & \multicolumn{2}{|c|}{ Mean $^{\star}$} & $1.30 \mathrm{E}$ & $4.05 \mathrm{D}$ & $7.70 \mathrm{C}$ & $11.30 \mathrm{~B}$ & $13.80 \mathrm{~A}$ & ------- \\
\hline
\end{tabular}

* Mean with the same letter are highly significantly differed by using Duncan's analysis. 
Metwally, A.M. et al.

Similar results were also observed by Bullard et al (1985) whom mentioned that Information is presented on the major groups of birds that attack these crops throughout the world. The following topics are then reviewed: (1) morphological characteristics, damage caused by birds and bird-resistant traits in sorghums and maize separately (2) general concepts of crop protection against birds and (3) economics of crop protection. Tolba (1999) in sorghum plantations in the percentage of Sparrows damage between sorghum varieties may be due mainly to the variation in plant morphology and phonology; agriculture practices and sparrow were a way of human inconvenience.

Fig. (2): Damage percentage at various growth stages of two sorghum varieties on different habitat during 2003 and 2004. 
Data in Table (2) revealed that there was significant difference between tested habitats and planted varieties whereas the sorghum variety (Giza 15) showed high damage in old land and newly reclaimed area (23.28 \& 7.84\%) during 2003 season but the mean damage in newly reclaimed land were decrease from old land, comprised with Dorado variety. The mean in old land $(5.24 \%)$ and newly reclaimed land were the mean $(3.24 \%)$ but the results in Table (2) during 2004, revealed that there was highly significant difference between tested habitats and planted whereas the mean in variety Giza 15 were $(21.24 \%)$ in old land and $(3.24 \%)$ in newly reclaimed land comprised with Dorado variety. The mean in old land was $4.64 \%$ and in newly reclaimed land was $1.40 \%$. The variation in the percentage damage mentioned above agreed with those obtained by Khattab (1993) who stated that the bird damage was lower at the newly reclaimed land when compared to old land. The same data were Obtained by Metwally et. al (1995) whom observed that damage due to birds occurred the different crops was markedly higher in the traditional land than in newly reclaimed land. Data in the previous tables show that there was highly significant difference between the examination dates of damage caused by birds of sorghum crop during 2003 \& 2004 .

The results revealed that the bird caused damage were attacked sorghum crop starting from the milky stage (3.00 \& 1.30\%). The damage was increased gradually during the doughy and mature stages (September month) $(5.40,8.65,15.65,16.80 \% \& 4.50,7.70,11.30,13.80 \%)$ respectively during $2003 \& 2004$. The bird caused damage attacked sorghum crop till the harvest may be due mainly to the morphology features of plants. Tolba (1999), mentioned that the damage stated during the doughy and milky stages, then increased gradually till the harvest time.

The results revealed that there was highly significant difference between the planted habitat and examined dates. The results revealed that the damage by birds of Sorghum crop decreased in first stages from appearance of plant heads in both habitats. The damage was increased gradually till the harvest. Respectively in old land the mean of total damage in each Sorghum variety Giza 15 and Dorado were recorded in the examined different dates $(2.90,6.70,11.80,24.00,25.90 \%$ \& 2.60, 7.50, 13.10, 18.90 , $22.60 \%$ ) during $2003 \& 2004$. But the mean of total damage in two variety mentioned above in newly reclaimed land were $(3.10,4.10,5.50,7.30,7.70 \%$ $\& 0.00,0.60,2.30,3.70,5.00 \%)$ respectively during $2003 \& 2004$. In Sharkia Governorate Khattab (1993) revealed that of Sorghum crop, the highest damage occurred at mature stage $(10.8 \& 8.3)$ at old land and newly reclaimed land) followed by dough stage $(7.3 \& 5.9 \%)$ and milk stage (5.8 \& $4.1 \%)$.

The maximum attack was recorded in variety Giza 15 during 2003 \& 2004 respectively $(5.40,9.40,14.30,23.90,24.80 \% \& 2.60,8.10,12.40$, $17.30,20.80 \%)$ comprised with the variety Dorado $(0.60,1.40,3.00,7.40$, $8.80 \% \& 0.00,0.00,3.00,5.30,6.80 \%$ ) respectively during $2003 \& 2004$. Also it was found that mean percentage of bird damage was more higher in 2003, than in 2004 in each two varieties. Statistical analysis of data in Table (2) 
showed that in 2003 there is significant difference between the sorghum varieties and examined dates comprised with 2004, the data in Table (2) shows that there is a highly significant difference between the cases mentioned above.

It had been observed that birds started to attack at appearance of plant heads till harvest. Also the losses decrease after grain ripeness. The results revealed that in old land the variety Giza 15 recorded were high damage during 2003 \& 2004 respectively $(5.60,12.40,20.40,38.20,39.80 \% \& 5.20$, $15.00,21.80,29.60,34.60 \%$ ) comprised with newly reclaimed land $(5.200,6.40,8.20,9.60,9.80 \% \& 0.00,1.20,3.00,5.00,7.00 \%)$ during 2003 $\& 2004$. The percentage damage in the variety Dorado recorded were in old land and newly reclaimed land but the high damage in old land during 2003 \& $2004(0.20,1.00,3.20,9.80,12.00 \% \& 0.00,0.00,4.40,8.20,10.60 \%)$ and newly reclaimed land the percentage damage were during $2003 \& 2004$ $(1.00,1.80,2.80,5.00,5.60 \% \& 0.00,0.00,1.60,2.40,3.00 \%)$

In general, data showed that the Sorghum variety (Giza 15) high susceptibility to birds especially in old land comprised with variety Dorado in old land or newly reclaimed land. The high damage in variety Giza 15 at specially and old land at generally returning to increase the bird damage than newly reclaimed land also the morphological and chemical features of sorghum plants. The statistical analysis of data in Table (2) Shows that in 2003 there was significant difference between the planted habitats, Sorghum varieties and examined dates but in 2004 the data in Table (2). Shows that there is highly significant difference between the factors mentioned above.

\section{REFERENCES}

Abd El-Gawad, K. H. ; Eraky, S.A.M. and Tolba, E.F. (2004). Food consumption as a measure of the population density of house sparrow ; Passer domesticus niloticus (L.) workshop on "Agricultural development in the Arab Nation, obstacles \& Solutions " Jan. $20-22$, 2004, Assiut, Egypt. 335 - 340.

Bullard, R.W.; York, J.O. and Russell, G.E. (ed.). (1985). Breeding for bird resistance in sorghum and Maize progress. In . plant. Breeding 1. PP. 193.

Coleman , J. D. ; Spurt, E. B. and Zydenbos, S.M. (2001). Farmer perceptions of bird damage and control in arable crops. New - Zealand - plant. Protection - volume - 54, - 2001 - proceedings - of - a conference, - Quality - Hotel, - Palmers ton - North, New - Zealand $14-16$ - August. PP $184-187$.

Khan, H.A. (2002). Damage patterns of house crow (Corvus splendens) on some food crops in Faisalabad, Pakistan. International. Journal. Of. Agriculture and Biology. 4 ( 4 ): $500-502$. 
Khattab, M.M. (1993). Biological, Ecological and Toxicological studies on harmful birds of agriculture and of Sharkia Governorate. M.Sc. Thesis Fac. Agric., Al - Azhar Univ. PP.199.

Metwally, A.M.; El - Deeb, H.H. ; and Abd El - Aal, S.; and Khataab, M.M. (1995). Birds damage to some ripening field crops under different conditions in Sharkia Governorate Al - Azhar J. Agric. Res., 21. 413 424.

Muhammad, U. (2004). Losses due to house sparrow to wheat crop in central Punjab. International. Journ. Of. Agriculture and Biology. 6 (3) : 541 543.

Poche, R.M.; Mian, M. U.; Hoqie, M.E. and Sultana, P. (1982). Rodent damage and burrowing characteristics in Bangladesh wheat fields. J. Will. Manage. $46: 139-147$.

Shafiq, M.M. and Umeed, K. (2001). House sparrow (Passer domesticus ) damage assessment to wheat crop in farm forestry area. Pakistan. Journal of Forestry. $51(2): 77-80$.

Soliman, A.M.A. (1993) Studies on arthropods associated with the harmful birds and their nests at Kafr El - Sheikh Governorate. M. Sc. Thesis Fac. of Agric. Zagazig Univ. PP.115.

Soliman, A.M.A. (1999) ). Ecobiological studies on some wild bird species at Kafr El - Sheikh Governorate with species reference to some Arthropods. Ph.D. thesis. Fac. Agric., Zagazig Univ. PP.203.

Tolba, F.M.T. (1999). Some ecological aspects on House sparrow attacking various crops in Assiut Governorate. M. SC. Thesis faculty of Agric., Assiut Univ. pp.105.

Wilson, B.M. (1993). Integrated approaches for population management of harmful birds in agriculture areas of Egypt. Ph. D. thesis. Institute of environmental studies and research, Ain Shams University, Egypt. 


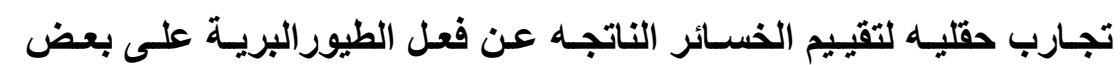

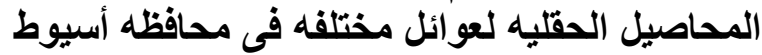

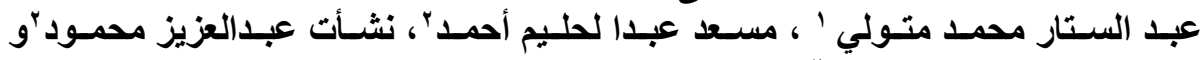

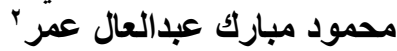

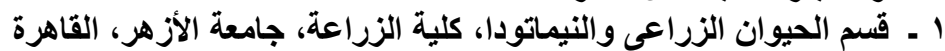

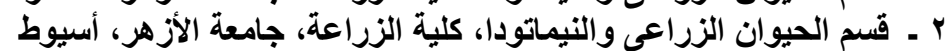

أجريت هذه الدراسة تحت عو ائل مختلفة فى محافظة أسيوط بهدف معرفة الخسائر الناتجة

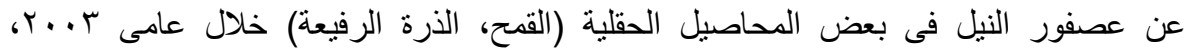

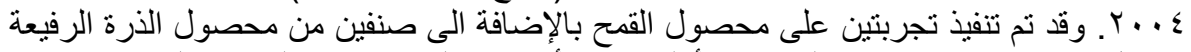

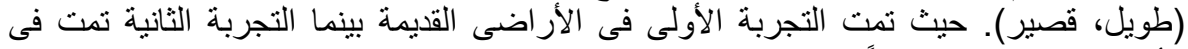

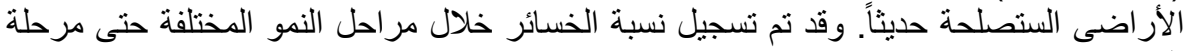

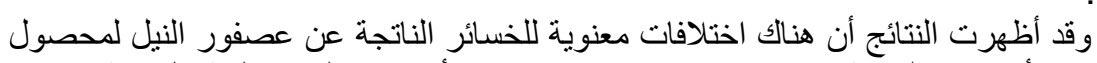

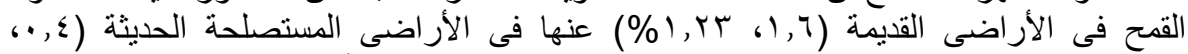

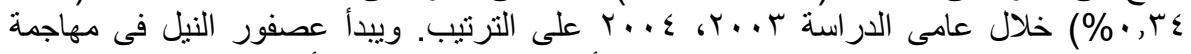

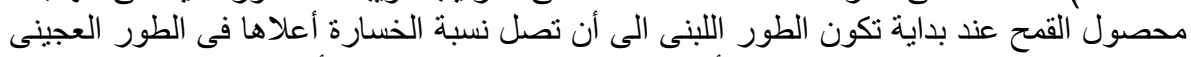

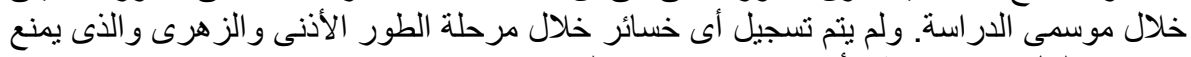

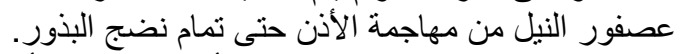

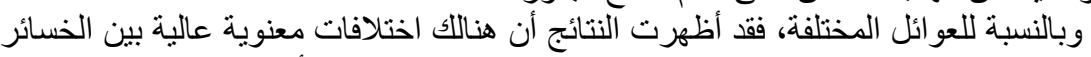

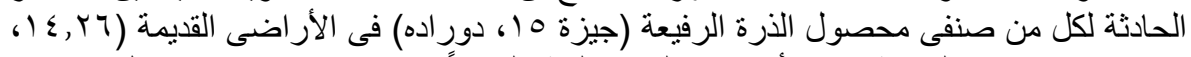

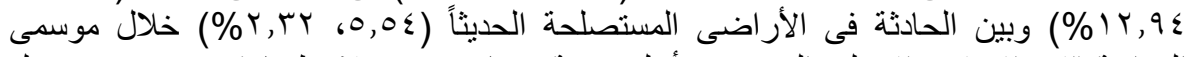

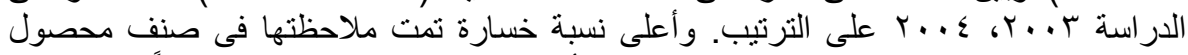

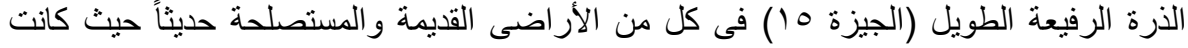

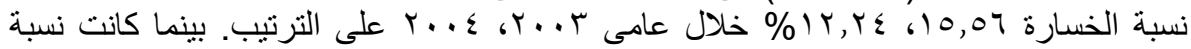

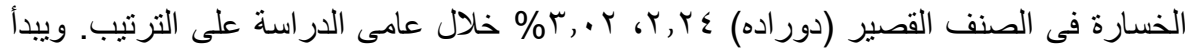

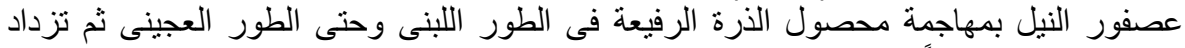
نسبة الخسارة تدريجياً حتى وقت الحصاد. 